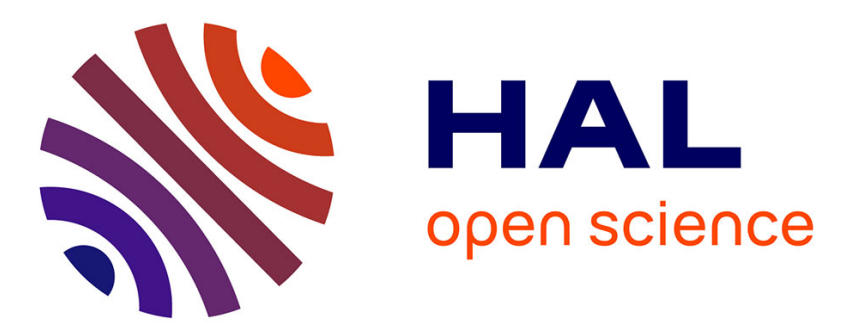

\title{
An analysis of the intention-realisation discrepancy in EU farmers' land investment decisions
}

Marianne Lefebvre, Meri Raggi, Sergio Gomez-Y-Paloma, Davide Viaggi

\section{To cite this version:}

Marianne Lefebvre, Meri Raggi, Sergio Gomez-Y-Paloma, Davide Viaggi. An analysis of the intentionrealisation discrepancy in EU farmers' land investment decisions. Revue d'Etudes en Agriculture et Environnement - Review of agricultural and environmental studies, 2014, 95 (1), pp.51-75. 10.4074/S1966960714011047 . hal-02519061

\section{HAL Id: hal-02519061 \\ https://univ-angers.hal.science/hal-02519061}

Submitted on 25 Mar 2020

HAL is a multi-disciplinary open access archive for the deposit and dissemination of scientific research documents, whether they are published or not. The documents may come from teaching and research institutions in France or abroad, or from public or private research centers.
L'archive ouverte pluridisciplinaire HAL, est destinée au dépôt et à la diffusion de documents scientifiques de niveau recherche, publiés ou non, émanant des établissements d'enseignement et de recherche français ou étrangers, des laboratoires publics ou privés. 


\title{
An analysis of the intention-realisation discrepancy in $\mathrm{EU}$ farmers' land investment decisions
}

\author{
Analyse des écarts entre les intentions d'achat de terres par les \\ agriculteurs européens et les achats réalisés
}

\author{
Marianne Lefebvre ${ }^{1}$, Meri Raggi ${ }^{2}$, Sergio Gomez-y-Paloma ${ }^{3}$ and Davide Viaggi ${ }^{4}$ \\ Revue d'Études en Agriculture et Environnement (2014), Volume 95(01):51-75 \\ DOI: $10.4074 /$ S1966960714011047, \\ Link to this article: http://necplus.eu/abstract_S1966960714011047
}

First submission: $15^{\text {th }}$ November 2012; Revised: $30^{\text {th }}$ April 2013; Accepted: $17^{\text {th }}$ September 2013; Published online: $07^{\text {th }}$ May 2014

\begin{abstract}
The objective of this paper is to explain the discrepancy between farmers' investment intentions and the observed realisations. We analyse the stated intentions with regard to investments in land on the part of 171 farmers in 6 EU case study areas (collected in 2006) and their realised investments between 2006 and 2009. While the farmers who had no intention to invest mostly follow their plans, only $36 \%$ of those who intended to invest in 2006 have done so by 2009 . We set up a recursive bivariate probit model in which intention is an endogeneous regressor of the realisation. We show that stated intentions are a reasonably good predictor of realised actions, and highlight drivers of the discrepancy between intentions and realisations, such as pessimistic expectations regarding the future of both agricultural markets and the farm when no successor is known. Some recommendations on the use of stated intention surveys to study the farming sector are provided.
\end{abstract}

Key words: stated intentions, survey, agriculture, investment, land, recursive bivariate probit

Résumé: L'objectif de cet article est d'expliquer l'écart entre les intentions d'achat de terres et les achats réalisés. Pour cela, nous analysons les intentions d'achat de terre (collectées en 2006) et les investissements réalisés entre 2006 et 2009 de 171 agriculteurs dans 6 pays européens. Alors que les agriculteurs qui n'avaient pas prévu d'investir suivent leurs intentions initiales, seulement $36 \%$ de ceux qui souhaitaient investir en 2006 ont réalisé leur investissement entre 2006 et 2009. Nous utilisons un modèle probit bivarié récursif dans lequel les intentions sont regresseurs endogènes des réalisations. Ce modèle montre que les intentions sont un relativement bon prédicteur des intentions, et met en évidence les déterminants de l'écart entre intentions et réalisations, comme des anticipations négatives concernant le futur, à la fois sur les marchés agricoles et au niveau de l'exploitation (notamment l'incertitude concernant la succession). Nous proposons des recommandations sur l'usage des enquêtes d'intention.

Mots clés: intention, enquête, préférences déclarées, agriculture, investissement, terre, probit bivarié récursif

\footnotetext{
${ }^{1}$ European Commission, Joint Research Centre, IPTS Seville, Spain

Corresponding author: Marianne.Lefebvre@ec.europa.eu; Tel: 0034954488314

${ }^{2}$ Department of Statistical Sciences, University of Bologna, Italy

${ }^{3}$ European Commission, Joint Research Centre, IPTS Seville, Spain

${ }^{4}$ Department of Agricultural Sciences, University of Bologna, Italy
} 
JEL codes: Q12, Q15, C83 


\section{Introduction}

The reliance on intentions or stated preferences data is becoming increasingly common when studying farmers' future decisions and adjustment to potential changes in their environment, such as changes to agricultural policy. For example, Bougherara and Latruffe (2010) have studied the potential impact of the decoupling of the Common Agricultural Policy (CAP) on land idling decisions of landowners in France. Bartolini and Viaggi (2011) and Raggi et al. (2012) have used stated intentions regarding changes in land use under two different policy scenarios to identify the determinants of changes in farmed area, as well as exit strategies.

Whereas intention-based surveys are commonly used in applied economics, there are only a few empirical studies measuring their reliability. Moreover, there is very limited evidence on the determinants of the intentions-realisation discrepancy, i.e. the gap between the stated intention and the realised action. Research on the stated intention-realisation discrepancy is made difficult from a practical point of view because it requires: i) following the same sample in at least two surveys, which is not easy in the context of agriculture due to the high exit rate from farming activities (Breustedt and Glauben 2007; Mishra, Raggi et al. 2010; Raggi, Sardonini et al. 2012); ii) having respondents answer the question about the same decision problem in two separate surveys (first on intentions and later on realisations), whereas the environment and the relevance of the questions may have evolved over time.

A few studies have overcome these difficulties and have compared stated intentions and actual behaviour. Yet they present contrasting results. Thomson and Tansey (1982) reported a series of surveys carried out in the 1970s on Scottish dairy farmers regarding herd size intentions, allowing for a comparison with the realisations expressed a few years prior. Relying on several data sources, they show that only between one-third and one-half of the respondents acted in compliance with their stated intentions. They also observe that one-fifth of the farms remaining in business between the two surveys took actions that were the opposite of their earlier stated intentions. They do not provide explanations of the determinants of these discrepancies. Vare et al. (2005), for their part, examine and compare farmers' succession plans (obtained from a survey) and actual succession decisions (calculated from FADN accountancy data). They found that 297 out of 348 farm households carried out their original intentions with regard to farm succession in Finland. They found that the discrepancy between intention and actual behaviour is significantly related to the farm operator's age: the older the farm operator is, the more likely an unplanned succession will take place. They conclude that intention surveys are weak predictor of farmers' future succession plans. Mitchell et al. (2011) compare intentions to participate in the Average Crop Revenue Election (ACRE) programme (collected through a mail survey 5 months before the decision was made) and actual enrolment (in the USDA Farm Service Agency). Their objective was to determine if the factors affecting intentions were the same as those affecting actual enrolment. The evidence is mixed: some variables explain both intentions and actual decisions, but others do not. The authors conclude that the information search undertaken by farmers prior to the sign-up deadline may have resulted in a change in farmers' understanding of ACRE and influenced their decisions, therefore explaining why enrolled farmers have different characteristics than the ones who initially intended to participate.

This paper contributes to the literature on the intention-realisation discrepancy in farmers' decisions by focusing on the special case of land investment in Europe during the period 2006-2009. The paper focuses on investments in land, as they are the major drivers of farming activity. Of the productive factors, land is the one which most often limits farm development 
and which is most directly applicable as an indicator of farm size. As a result, change in farmland size and land markets are the structural factors most studied in the literature (Ciaian, Kancs et al. 2010). Investment in land depends on diverse and complex economic factors such as structural change in farming, competition for land use, speculative forces in the land market, the design of the agricultural policy etc. (Ciaian, Kancs et al. 2012a). Farmers operating family farms also have individual reasons to sell or keep their land, including family traditions, prestige, and lifestyle values. When land is sold, it is often for reasons such as retirement or the death of the owner. The analysis of the intention-behaviour discrepancy in land investment is particularly interesting as investing in land requires time for planning and realisation, which makes it more likely that farmers develop the intention to invest a few years before realising the investment. However, the timing of operations in any land transaction may be slow and delays are possible, which can impact on the connection between intentions and actions.

The objective of this paper is to explain the discrepancy between farmers' intentions with respect to land investment and the observed realisations in order to provide insights into the robustness of stated intentions as a means of predicting farm behaviour and related policy impact. ${ }^{5}$ This general objective is achieved through the following specific objectives: i) to determine whether the realised land investments between 2006 and 2009 are correlated with the stated intentions in 2006, despite the rapidly changing environment; ii) to identify the factors explaining the intention-realisation discrepancy at the individual level; and iii) to provide recommendations on the use of stated intentions surveys to study the farming sector.

In order to achieve the objectives of the paper, we use data from a survey that was carried out in $6 \mathrm{EU}$ case studies in 2006 and replicated in 2009. The period during which the two surveys were conducted was marked by two major events. First, the 2003 CAP reform, in which agricultural payments were decoupled from production, was gradually implemented from 2005 onwards. Land investment decisions are likely to be effected by decoupling through its impacts on farmers' access to capital markets (Vercammen 2007), on farmers' attitudes with respect to risk (Hennessy 1998; Koundouri, Laukkanen et al. 2009; Sckokai and Moro 2009) or on land prices and land rental decisions (Ciaian and Kancs 2012; Kilian, Antón et al. 2012; O'Neill and Hanrahan 2012). Second, the global economic crisis also impacted the agricultural sector through higher input prices, reduced access to credit, and the limitation of production contracts (FAO 2010). This context, characterised by rapidly changing economic conditions, implies a lower propensity to invest and can be expected to contribute to the discrepancy between intentions and behaviour. In other words, the relation planned-realised investments in the current exercise may be expected to be weaker (higher discrepancy) than the one that would be found in a hypothetically constant environment.

The paper is structured as follows. Background information on the pros and cons of the use of stated intention surveys are presented in section 2 . In section 3 , we introduce the data and the model used. The results are presented in section 4 , while a conclusion is provided in section 5 .

\footnotetext{
5 Readers should be aware that the main objective of the paper is not to understand the determinants of farm investments in land per se (see Bartolini and Viaggi (2011) or Viaggi et al (2011b) for papers on this issue). Rather, it aims at understanding the drivers of the differences between the stated intentions and the realisations.
} 


\section{Background: the pros and cons of the use of stated intention surveys}

Stated intentions surveys have been extensively used in marketing research since the 1970 s to analyse consumer purchase intentions and forecast the adoption of new products (Cattin and Wittink 1982). Likewise, such surveys have been used in the transport literature since the 1980s to analyse citizens' willingness to use different transport means, hence contributing to the evaluation new transport infrastructure projects (Kroes and Sheldon 1988). The reliance on intentions is also becoming more common in the field of agriculture and agricultural policy studies.

Surveys of farmers' intentions are used mainly for two reasons. First, they are an attractive tool for researching situations for which revealed preference data is scarce or inexistent (Louviere, Hensher et al. 2000; Bougherara and Latruffe 2010). In particular, stated intentions are useful to investigate hypothetical situations, which is a common need in ex-ante policy evaluations. For example, Mattison and Norris (2007) have studied UK farmers' intentions to produce biofuel crops, in order to estimate potential biofuel production when refining capacity becomes available. The farmers interviewed had to state their intentions with regard to biofuel crop production under a hypothetical scenario in which refining capacity would exist. In Bartolini and Viaggi (2011) and Raggi et al. (2012), the authors asked farmers their intentions in reaction to an extreme and hypothetical/unobserved policy change (total removal of the CAP).

The second reason for using intention surveys is that survey results provide good insight into farmers' expectations about the evolution of their environment and business confidence, which is otherwise difficult to capture (Thomson and Tansey 1982). Intention data reveal respondents' frame of mind which is very likely to shape actions in the short term (Harvey 2000). Given the present high level of uncertainty surrounding farming (uncertainty regarding agricultural prices in the short term, the future of the Common Agricultural Policy in the medium term and climate change in the long term), behavioural components such as farmers' perceptions and attitudes toward risk are likely to play a fundamental role in agricultural decisions (Just 2008). When complex human decisions are involved, surveys on intentions may be more accurate than programming models in the representation of behaviours as they usually require fewer assumptions than models and can rely on the respondents' perception to provide a synthesis of their likely reactions to complex context variables. In these cases, it is reasonable to rely also on surveys of stated intentions, as a complement to programming models, allowing for a consistent comparison of results under different scenarios (Viaggi, Raggi et al. 2011a).

Despite these advantages, the ability of stated intentions to predict real behaviours is debated in the economic literature. Economists are sceptical about the credibility of stated preferences and rely more often on past behaviour to predict future behaviour (revealed preferences) (Wong and Sheth 1985; Manski 1990). On the contrary, selected branches of psychology (e.g. social psychology) take intentions seriously and consider intention to be a mental state that causally precedes behaviour (Fishbein and Azen 1975). ${ }^{6}$ There are two possible types of

\footnotetext{
${ }^{6}$ It should be noted that the very act of measurement may in fact alter the association between intentions and behaviour. Indeed, studies show that asking persons to predict their future behaviour tends to inflate the likelihood that they will engage in that behaviour, a phenomenon called "self-generated validity effect" (Chandon, Morwitz et al. 2005).
} 
inconsistencies between stated intentions and realisations: errors of commission, when a respondent states that he will choose an alternative but then fails to actually do so; and errors of omission, when a respondent does not state that he will choose an alternative but actually does so (Fujii and Gärling 2003).

One obvious reason why farmers' decisions may not match their original intentions is that more, or new, information becomes available following the survey, either because the environment has changed (economic conditions relevant for the decision, etc.) or because the farmer did not previously have access to the information (Thomson and Tansey 1982; Manski 1990; Vare, Weiss et al. 2005). The intention-realisation gap is likely to increase with the time span between the intention survey and the collection of information on realised behaviours, as the environment is more likely to change over a longer period of time. It should be taken into account that, for the purchase of land, the time lag between the moment in which a decision to purchase is taken and the actual implementation of the action can be long for multiple reasons, including delays in finding an appropriate counterpart, dealing with legal requirements, etc., which increases the probability of changes in the available information or context variables However, a short period between the intention survey and the realised decisions survey does not necessarily mean that the discrepancy between intentions and realisations will be minimal, as this will depend on the timing of changes in the context. Moreover, farmers can be time-inconsistent, i.e. their preferences at the time of planning their future activities may differ from their preferences at the time of implementing them (Horowitz 1992).

Beyond the factors related to context, the literature points out two biases likely to impact farmers' responses in intention surveys, hence explaining the deviation between their stated intentions and their realisations. First, the 'negligence bias' is related to the fact that farmers devote too little time to answering the questionnaire and thus might not reveal their true preferences. They might also feel obliged to answer questions about intentions even though they have not yet made specific plans (Bagozzi and Yi 1989; Vare, Weiss et al. 2005). Yet, the usual difficulties related to questionnaire design are increased in intention surveys due to the need to pre-judge the basis upon which farmers respond to questions about their plans for the future. Some may report their intentions on the basis of the actual environment, unlikely to persist, or extrapolate price and income trends and report their intentions based on these (unreported) assumptions. In a stated intention survey, the researcher should attempt to define explicitly the conditions under which intentions are to be formulated, but the possibility of respondents ignoring or disagreeing with these assumptions cannot be disregarded (Thomson and Tansey 1982). The second type of bias is the 'manipulation bias,' i.e. responses might be biased if respondents think that their answers can influence the result of the survey and the subsequent policy decision (Thomson and Tansey 1982). Biased responses arise from the desire to look socially responsible or to exert influence toward a desired end (Fujii and Gärling 2003). These are important concerns in studies regarding agricultural policy, a field in which farmers' lobbies are powerful and it may seem possible for the respondent that parties involved in policy negotiations may make use of the results. 


\section{Data and model}

\subsection{Data}

We use data from a survey that was carried out on 171 farms in 6 EU case studies (France, Greece, Italy, Netherlands, Poland, Spain) in 2006, and replicated in 2009 in the same sample. The sample was selected through a non-probability sampling procedure, based on a proportional stratified sample rationale and complemented by expert judgment. It should be noted that the structure of the sample was not originally conceived for the purpose of this study. ${ }^{7}$ The sample was built in such a way as to provide a wide range of coverage of European agricultural systems, though with a small number of interviews per system, relying on in-depth information rather than on large numbers of interviews. The sample includes different countries (6 interviews in France, 15 in Spain, 12 in Greece, 75 in Italy, 4 in Netherlands, 59 in Poland), different altitudes (59 mountain farms, 112 in plain), different specialisations (55 arable crops farms, 58 livestock farms, 58 perennial farms) and different production methods (49 organic farms and 122 conventional farms). Data were collected through face-to-face interviews about the farm and the household, their perspectives, their intended investments and their reaction to policy change. The main variables of interest for this paper are the stated intention to invest in land in the next 5 years (collected in 2006) and the investments made between 2006 and 2009 (computed from the information collected in 2009 on the presently owned land and the purchase year). ${ }^{8}$

\subsection{Model}

The discussion in section 2 highlights the fact that economists are sceptical about the absence of discrepancy between intentions and realisations. A first set of reasons is inherent in the different perceptions and motivations of respondents when formulating a statement about their future behaviour and when taking an actual decision. A second group of reasons can be found in external conditions and information availability that may change between the time of the statement and the time of the realisation of the investment. These difficulties appear even more prominent when they are connected to the process of land investment decisions, which are known to be a rather complex (Lagerkvist 2005). While the drivers of decisions to invest in land have been analysed in the literature, the literature does not provide a convincing/rigorous explanation of the micro-mechanisms of decision-making, intention formation and their connection with actual behaviour. In fact, most of the economic literature assumes that the land purchase process is driven by expected profits (though mediated by several factors, such as uncertainty) and that the decision to invest is made first, followed by the actual purchasing behaviour (Pyndick 1991; Feinerman and Peerlings 2005). This is also consistent with the theory of planned behaviour, which assumes a consequentiality/causality

\footnotetext{
${ }^{7}$ See Viaggi, Raggi et al (2011a) for a description of the complete methodology of the project and Viaggi, Raggi et al (2010) and Viaggi, D., M. Raggi, et al. (2011b) for the main results. Due to missing data, we use a subsample of the total sample in this paper, which included 268 farms in 2006 and 182 in 2009, in a total of 8 countries.

${ }^{8}$ As the 2006 question concerned the expected investments in the next 5 years (2006-2011), a possible criticism is that farmers who have not invested yet in 2009 can still realise their investments in 2010 and 2011, without departing from their original intentions. However, an inspection of further investment intentions as stated in 2009 reveals that only 10 farms have the intention to invest in land in the first 2 years after 2009, and they are well distributed across categories with respect to intentions in 2006 and actual investment in between. Therefore, we considered that the potential further investment was not very relevant and preferred to avoid corrections of the realised investment with the additional intentions, while being aware of the slight time discrepancy.
} 
in the process of attitude formation, intentions and actual behaviour (Ajzen 1991). This causality will be observed only if intention to invest goes with an active search for information, attention to signals coming from the market and preparatory actions (e.g. renting in land as a step towards purchasing, ensuring liquidity availability etc.). In the transaction cost theory, the above actions are ex-ante activities needed to carry out transactions (Allen and Lueck 2002).

However, once the intention to purchase land is established, several factors may affect its actual realisation. First, land may not be available at the right time and within the desired distance from the farm, or the purchase conditions may not be those expected. Also, context conditions may change, e.g. credit availability, agricultural product prices, prices of land itself, opportunity costs of capital etc. can change compared with the time at which the intention was established.

Altogether, the considerations above allow for the formulation of the hypothesis that purchasing intention can be a proxy of actual behaviour as it is a potential determinant of further land purchasing behaviour. In order to explore the link between intentions (collected in 2006) and realisations (between 2006 and 2009), we have selected a model that accounts for the fact that intention to invest is expected to have an influence on the probability to realise an investment. One solution would be to use a simple probit model where intentions are included as a regressor to explain realisation. Yet this would not take properly into account the fact that we may expect that some unobserved heterogeneity has an influence on both the intention and the realisation of investments. For example, budget constraints can affect both the intention to invest and the realisation of an investment. On the other hand, it is also reasonable to expect that some variables that would affect actual investment are different from those that affect intentions (e.g. context conditions after the intention is expressed) (Dong, Hennessy et al. 2013). In order to take these features consistently into account we specified the model as a recursive bivariate probit model (Heckman 1978; Maddala 1983; Dong, Hennessy et al. 2013). This allows controlling for unobserved heterogeneity by allowing correlation between the errors that capture unobserved factors and, at the same time, consider the structural features of the problem by using the predicted values of intentions as regressor in the realisation equation.

The two dependent variables, $\mathrm{Y}_{1}$ (intentions) and $\mathrm{Y}_{2}$ (realisation), are modelled as binary variables with $Y_{1}=1$ when the farmer has declared an intention to invest in $2006\left(Y_{1}=0\right.$ otherwise) and $\mathrm{Y}_{2}=1$ when the farmer has realised an investment between 2006 and 2009 ( $\mathrm{Y}_{1}=0$ otherwise). We assume that values of the two observed binary variables $\mathrm{Y}_{1}$ and $\mathrm{Y}_{2}$ are determined by two latent variables $\mathrm{Y}_{1}{ }^{*}$ and $\mathrm{Y}_{2}{ }^{*}$. The latent variable $\mathrm{Y}_{1,2}{ }^{*}$ can be interpreted as the unobservable net benefit from purchasing an additional hectare of land. From economic theory, it can be assumed that a farmer will decide to expand the farmed area when the perceived net benefit of the potential investment in land is positive, i.e. the willingness to pay for an additional hectare of land is higher than the cost. 
The general specification of the bivariate probit model is as follows:

$$
\begin{aligned}
& \text { (1) } \mathrm{Y}_{1}^{*}=\alpha^{\prime} \mathrm{x}_{1}+\varepsilon_{1} \\
& \text { with }\left\{\begin{array}{l}
Y_{1}=1 \ldots \text { if } \ldots Y_{1}^{*}>0 \\
Y_{1}=0 \ldots \text { otherwise }
\end{array}\right. \\
& \text { (2) } \mathrm{Y}_{2}^{*}=\beta^{\prime} \mathrm{x}_{2}+\lambda \mathrm{Y}_{1}+\varepsilon_{2}
\end{aligned}
$$

where $\mathrm{x}_{1}$ and $\mathrm{x}_{2}$ are vectors of exogenous variables, and the errors $\varepsilon_{1}$ and $\varepsilon_{2}$ have bivariate normal distribution. Moreover, we assume that:

$$
\begin{aligned}
& E\left[\varepsilon_{1} \mid x_{1}, x_{2}\right]=E\left[\varepsilon_{2} \mid x_{1}, x_{2}\right]=0 \\
& \operatorname{Var}\left[\varepsilon_{1} \mid x_{1}, x_{2}\right]=\operatorname{Var}\left[\varepsilon_{2} \mid x_{1}, x_{2}\right]=1 \\
& \operatorname{Cov}\left[\varepsilon_{1}, \varepsilon_{2} \mid x_{1}, x_{2}\right]=\rho
\end{aligned}
$$

In such a model, the intention equation (1) is estimated by way of a probit model. Then, the predicted values from the intention equation are inserted into the realisation equation (2). The recursive model with two binary dependent variables can be estimated using full information maximum likelihood (Greene 2011) . We use the robust option to obtain heteroscedasticityconsistent standard errors.

\subsection{Explanatory variables}

We have reviewed the literature on land investment decisions to define the set of possible explanatory variables. They can be classified into the following three categories: farm characteristics, farmer characteristics and financial and economic variables. The latter categories also include expectations about key parameters of the future economic context (e.g. prices).

\subsubsection{Farm characteristics:}

The decision to acquire an extra surface of land can be related to the already available land. However, the impact of the total surface of the farm on land purchase decisions is ambiguous: large farms usually benefit from better financial endowment to expand further than small farms; on the other hand small farms may have higher propensity to expand to benefit from economies of scale. To take into account possible non-linear effects of size, we include total farm size in hectares in quadratic form.

Most farmers own at least a part of the land they are farming. Farmers renting the majority of their cultivated land may be willing to increase the share of owned land. On the other hand, owning a small amount of land can be an indicator of financial constraints and/or preferences towards land rental. In that case, land tenants will be less likely to invest in land. Accordingly, we include the number of hectares of land owned by the farmer in the model.

Land transactions occur when agents have heterogeneous marginal productivity for a hectare of land. In the absence of data on marginal productivity, we use labour availability, farm 
specialisation (crop, livestock, perennial) and the production system (organic or conventional) to capture the heterogeneity between farms likely to trigger transactions. The specialisation taken as reference is livestock, i.e. we analyse the impact of being specialised in a crop or perennial on the probability to invest, as compared to being a livestock farm. Use of other inputs such as labour is also likely to influence the extent to which the farmer purchases land since land and non-land inputs may be substitutes or complements. We include labour use onfarm, distinguishing between internal and external labour. This is motivated by the fact that different categories of labour may result in different flexibility in labour re-allocation and/or different labour costs.

The dummy for farms situated in mountain regions accounts for the lower agricultural productivity due to the existence of natural handicaps in such areas, and the lower availability of land for purchase in these regions, which can reduce the intention to invest (Bartolini and Viaggi 2012).

\subsubsection{Farmer characteristics:}

The legal status of the farm is likely to impact on investment decisions as the farmer's objectives may be different if he is an individual farmer or if he represents a legal entity such as a cooperative or a limited company. Moreover, individual farmers may face greater financial constraints to expand further, while having more flexibility in their decision-making hence allowing them to access household financial resources to provide funding for the farm, particularly in times of crisis. The overall effect of being an individual farmer on land investment is therefore ambiguous. We include a dummy equal to one if the farmer operates as an individual farmer.

The stage of the farm household life cycle, often approximated as the owner's age, and the expectations regarding the continuation of farming activity (approximated by the presence/absence of a successor within the household), are also likely to explain investments in land. Older farmers may not wish to farm as actively as younger farmers and therefore invest less (Weiss 1998). On the other hand, younger farmers may not be able to invest because of inexperience or financial constraints. Age can also be a proxy of farmers' risk aversion, which is likely to impact on investment under uncertainty (Knighta, Weirb et al. 2003). To take into account possible non-linear effects of age, we have considered the possibility of including age in quadratic form. Moreover, we take into account whether the farmer has a successor. More precisely, we use a dummy indicating the uncertainty around the succession (=1 if the response to the question "Does the farm have a successor?" is "do not know"). We could also have used a dummy indicating the existence of a successor (=1 if the response is "yes"), but the prediction power of this variable is lower.

The farmer's level of education can also be considered a key element in explaining different behaviours in the presence of transaction costs, which can constitute noteworthy constraints to land transactions (Allen and Lueck 2002). Higher education can favour decision planning, therefore impacting on the intention to invest.

\subsubsection{Financial and economic variables:}

Economic and financial variables, such as farm revenues and access to credit, are typically used to explain investment behaviour. Unfortunately, our data set does not include such information, though some structural variables (such as farm size) can be thought of as proxies. 
A potentially important variable, present in the survey, is the type of CAP payment received. The farmers in the sample receive direct CAP payments, but with different allocation mechanisms depending on the country in which they operate. In Poland, direct payments are allocated according to the Single Area Payment System (SAPS). SAPS is a simplified income support scheme which was offered to the Member States who joined the EU in 2004 and 2007 (EU-12) as an option at the date of accession in order to facilitate the implementation of direct payments. The level of the payment is obtained by dividing the country's annual financial envelope with its respective utilised agricultural area. It is simpler than the Single Payment System (SPS) because there is no need to establish and administer payment entitlements. However, it does not offer to farmers the flexibility of entitlements based on individual needs, such as sales or lease. We know from the literature that the design of agricultural subsidies has an impact land markets (Guyomard, Le Mouël et al. 2004; Courleux, Guyomard et al. 2008; Ciaian and Kancs 2012; Kilian, Antón et al. 2012). We therefore expect this policy variable to impact land investment decisions. In our model, the dummy SAPS country takes the value 1 for Polish farms, and 0 for the farms in the other countries where direct payments are allocated according to the SPS.

Expectations have a crucial role in investment decisions, as the expected profitability of an investment is equal to the discounted sum of future payoffs associated to the investment. Our data set includes information on the conditions that the farmer expects for output and input prices in 5 years time (with respect to the conditions prevailing at the time of the survey). Optimistic expectations regarding output (i.e. increase in crop and livestock prices) are likely to favour investment as the value of the crops produced on extra land is expected to be higher in the future. Optimistic expectations regarding costs (i.e. decrease in labour and capital costs and input prices) are likely to favour investment as the costs of farming the extra land are expected to be lower in the future and, therefore, the profitability of the extra crops grown will be higher.

We take the value of the variables in 2006 to explain intentions. Moreover, in order to capture the impact of the change in the economic context, we rely on 2009 data for quantity of labour (internal and external), expectations on future prices and uncertainty concerning the succession of the farm. These variables have been selected as those potentially amenable to explain investment realisation and with the higher potential for change between 2006 and 2009. The investments realised between 2006 and 2009 may have been undertaken under conditions which are neither those observed in 2006, nor those of 2009. Nevertheless, we use 2009 data as a proxy for the external conditions of the period 2006-2009.

Several other factors are likely to explain the land purchase decision but are not accounted for by the set of available variables. Examples include the farmer's ability to extract income from land, the actual existence of contiguous plots of land for sale, the farmer's attitude toward land market participation, family asset management strategies, attitudes toward risk, etc. (O'Neill and Hanrahan 2012). As a result, similarly to the majority of studies in this field, these effects are expected to remain incorporated in the error term. 


\section{Results and discussion}

The results are illustrated in three steps. First we provide a descriptive account of stated intentions vs. realisation in the sample. Second, we analyse descriptive information about the farmers who expressed different intentions or land investment behaviour. In the third step we illustrate the results of the recursive bivariate probit model.

With respect to the first point, in order to measure the intention-realisation discrepancy, we rely on two indicators: i) the number of farms for which a difference between planned and realised investments is observed; and ii) the correlation between stated intentions and realisations. In our sample, 127 farms ( $74 \%$ of the total) have behaviours consistent with their intentions. The vast majority of these farms (106) stated no intention to invest in 2006 (Table 1). The discrepancy between stated intentions and realised investments in land concerns 44 subjects out of 171. For 37 of them, the discrepancy can be classified as an error of commission (the farmer stated an intention to invest, but did not) and 7 as an error of omission (the farmer had no intention to invest, but did). In particular, among those who planned to invest in 2006, only 36\% did so between 2006 and 2009. Stated intentions to invest and realised investments are positively and significantly correlated (coefficient of correlation or Cohen (1988) 's effect size: $\mathrm{Phi}=0.3840, \operatorname{Pr}=0.00$ ).

Table 1: Number of farmers that stated an intention to invest and realise their investments in land

\begin{tabular}{|c|c|c|c|c|}
\hline & & \multicolumn{2}{|c|}{ Intention to invest in 2006} & \\
\hline & & No & Yes & Total \\
\hline \multirow{3}{*}{$\begin{array}{c}\text { Realisation in } \\
2009\end{array}$} & No & $\begin{array}{c}106 \\
\text { Among those who had no } \\
\text { intention to invest, 94\% did not } \\
\text { invest }\end{array}$ & $\begin{array}{c}37 \\
\text { Errors of commission }\end{array}$ & 143 \\
\hline & Yes & $\begin{array}{c}7 \\
\text { Errors of omission }\end{array}$ & $\begin{array}{c}21 \\
\text { Among those who stated an intention } \\
\text { to invest, } 36 \% \text { have invested }\end{array}$ & 28 \\
\hline & Total & 113 & 58 & 171 \\
\hline
\end{tabular}

In a second step we explore the factors explaining the intention-realisation discrepancy by presenting the differences between the average characteristics of the farmers with an intention to invest and those who do not intend to invest, and the differences between the average characteristics of the investors and those of the non-investors (Table 2). We also present the p-values of the Mann Witney test of the null hypothesis that the two populations have the same distribution. For binomial variables, we rely on the Pearson's chi-squared test. The test show that livestock farms are better represented in the investors' pool than in the noninvestors, both for intentions and realisations. On the contrary, farmers growing perennial crops are significantly less numerous among the investors than the non-investors. Moreover, farms situated in Poland are more likely to state an intention to invest without later realising it, compared to the farms situated in the older EU member states. In addition, the education levels of those who intend to invest exceed those of the farmers with no investment intentions, 
and the same is true for the realisations. The investors are younger, have larger average farm sizes and own more land. They also have less uncertainty concerning succession than noninvestors. We do not find any significant differences in 2006 expectations regarding future prices and costs among those who intended to invest and the others (2006), nor do we in 2009 among the investors and non-investors.

Table 2: Respondent average characteristics by type of decision (full sample)

\begin{tabular}{|c|c|c|c|c|c|c|c|}
\hline & $\begin{array}{l}\text { Variable name } \\
\text { in the model }\end{array}$ & $\begin{array}{c}\text { No } \\
\text { Intentio } \\
n\end{array}$ & $\begin{array}{c}\text { Intentio } \\
\mathrm{n}\end{array}$ & $\begin{array}{c}\text { Mann } \\
\text { Witne } \\
\text { y or } \\
\text { chi } 2 \\
\text { tests } \\
\text { (p- } \\
\text { value) }\end{array}$ & $\begin{array}{c}\text { No } \\
\text { Realisatio } \\
n\end{array}$ & $\underset{\mathrm{n}}{\text { Realizatio }}$ & $\begin{array}{c}\text { Mann } \\
\text { Witne } \\
\text { y or } \\
\text { chi } 2 \\
\text { tests } \\
\text { (p- } \\
\text { value) }\end{array}$ \\
\hline \multicolumn{8}{|l|}{$\begin{array}{l}\text { Farm } \\
\text { characteristics }\end{array}$} \\
\hline Crop [freq in \%] & D_crop & 35 & 26 & 0.21 & 30 & 43 & 0.19 \\
\hline $\begin{array}{l}\text { Livestock [freq in } \\
\% \text { ] }\end{array}$ & & 27 & 46 & 0.012 & 31 & 50 & 0.049 \\
\hline $\begin{array}{l}\text { Perennial [freq in } \\
\% \text { ] }\end{array}$ & D_perenial & 37 & 28 & 0.21 & 39 & 7 & 0.001 \\
\hline $\begin{array}{l}\text { Individual farm [freq } \\
\text { in \%] }\end{array}$ & D_indfarm & 75 & 86 & 0.10 & 77 & 85 & 0.37 \\
\hline $\begin{array}{l}\text { Mountain area [freq } \\
\text { in \%] }\end{array}$ & & 31 & 41 & 0.75 & 37 & 21 & 0.11 \\
\hline $\begin{array}{l}\text { Organic production } \\
\text { [freq in \%] }\end{array}$ & & 28 & 29 & 0.89 & 29 & 28 & 0.99 \\
\hline $\begin{array}{l}\text { Total land operated } \\
\text { in } 2006 \text { [ha] }\end{array}$ & total_land & 54.73 & 50.20 & 0.36 & 48.19 & 78.79 & 0.0015 \\
\hline $\begin{array}{l}\text { Land owned in } 2006 \\
\text { [ha] }\end{array}$ & land_owned & 36.90 & 29.05 & 0.29 & 32.65 & 42.35 & 0.018 \\
\hline $\begin{array}{l}\text { Internal workforce } \\
\text { available on farm in } \\
2006 \text { [hours/year] }\end{array}$ & labour_int_2006 & 4140.5 & 4789.85 & 0.15 & & & \\
\hline $\begin{array}{l}\text { External workforce } \\
\text { employed in } 2006 \\
\text { [hours/year] }\end{array}$ & labour_ext_2006 & 1644.5 & 1787.51 & 0.007 & & & \\
\hline $\begin{array}{l}\text { Internal workforce } \\
\text { available on farm in } \\
2009 \text { [hours/year] }\end{array}$ & labour_int_2009 & & & & 4127.76 & 4168.75 & 0.80 \\
\hline $\begin{array}{l}\text { External workforce } \\
\text { employed in } 2009 \\
\text { [hours/year] }\end{array}$ & labour_ext_2009 & & & & 1342.76 & 1078.21 & 0.56 \\
\hline
\end{tabular}

_D indicates dummy variable 
Table 2 - following-: Respondent average characteristics by type of decision

(full sample)

\begin{tabular}{|c|c|c|c|c|c|c|c|}
\hline & $\begin{array}{l}\text { Variable name } \\
\text { in the model }\end{array}$ & $\begin{array}{c}\text { No } \\
\text { Intention }\end{array}$ & Intention & $\begin{array}{c}\text { MW } \\
\text { or chi } \\
2 \\
\text { tests } \\
\text { (p- } \\
\text { value) }\end{array}$ & $\begin{array}{c}\text { No } \\
\text { Realization }\end{array}$ & Realisation & $\begin{array}{c}\text { MW } \\
\text { or chi } \\
2 \\
\text { tests } \\
\text { (p- } \\
\text { value) }\end{array}$ \\
\hline \multicolumn{8}{|l|}{$\begin{array}{l}\text { Farmer } \\
\text { characteristics }\end{array}$} \\
\hline $\begin{array}{l}\text { Age of farm head in } \\
2009 \text { [years] }\end{array}$ & head_age & 51.75 & 48.5 & 0.12 & 51.44 & 46.57 & 0.08 \\
\hline $\begin{array}{l}\text { Education level of } \\
\text { the farm head in } \\
2009 \\
\text { [from } 1 \text { to 6] }\end{array}$ & head_edu & 2.875 & 3.35 & 0.004 & 2.96 & 3.39 & 0.047 \\
\hline $\begin{array}{l}\text { Uncertainty on the } \\
\text { existence of a } \\
\text { successor in } 2006 \\
\text { [freq in \%] }\end{array}$ & D_suc_2006 & 30 & 21 & 0.19 & & & \\
\hline $\begin{array}{l}\text { Uncertainty on the } \\
\text { existence of a } \\
\text { successor in } 2009 \\
\text { [freq in \%] }\end{array}$ & D_suc_2009 & & & & 35 & 18 & 0.076 \\
\hline \multicolumn{8}{|l|}{$\begin{array}{l}\text { Financial and } \\
\text { economic variables }\end{array}$} \\
\hline $\begin{array}{l}\text { SAPScountry } \\
\text { (Poland) [freq in \%] }\end{array}$ & D_SAPS & 23 & 57 & 0.00 & 33 & 39 & 0.56 \\
\hline $\begin{array}{l}* \text { future prices of } \\
\text { crop and livestock } \\
2006-2011[-1,0,1]\end{array}$ & Expoutput_2006 & 0.36 & 0.32 & 0.56 & & & \\
\hline $\begin{array}{l}\text { *future input prices } \\
2006-2011[-1,0,1]\end{array}$ & & 0.23 & 0.2 & 0.96 & & & \\
\hline $\begin{array}{l}\text { *future labour costs } \\
2006-2011[-1,0,1]\end{array}$ & & 0.84 & 0.86 & 0.96 & & & \\
\hline $\begin{array}{l}\text { *future capital costs } \\
2006-2011[-1,0,1]\end{array}$ & & 0.76 & 0.85 & 0.31 & & & \\
\hline $\begin{array}{l}* \text { future prices of } \\
\text { crop and livestock } \\
2009-2014[-1,0,1]\end{array}$ & Expoutput_2009 & & & & -0.21 & -0.08 & 0.50 \\
\hline $\begin{array}{l}\text { *future input prices } \\
2009-2014[-1,0,1]\end{array}$ & & & & & 0.26 & 0.48 & 0.32 \\
\hline $\begin{array}{l}\text { *uture labour costs } \\
2009-2014[-1,0,1]\end{array}$ & & & & & 0.03 & -0.29 & 0.12 \\
\hline $\begin{array}{l}\text { *future capital costs } \\
2009-2014[-1,0,1]\end{array}$ & & & & & 0.07 & 0.38 & 0.11 \\
\hline$N$ & & 113 & 58 & & 143 & 28 & \\
\hline
\end{tabular}

* Expectations for the period 2006-2011 or 2009-2014

$[-1=$ prices will decrease, $0=$ prices will be stable , $1=$ prices will increase $]$ 
In the third step, we use the recursive bivariate probit model presented above to identify potential drivers of the intention-realisation discrepancy. Estimations are presented in Table 3. This model fits the data relatively well. The estimated correlation $(\rho)$ between the errors of the two probit models is not statistically significant. This suggests that we could estimate intentions and realisations separately, without accounting for error correlation, provided that intentions are also considered among the explanatory variables for actual investments.

The final sample used for the analysis contains 131 observations. Forty observations were lost because they include missing data in explanatory variables in the model. The final choice of variables included in the probit model was made on the basis of log-likelihood comparisons between different models and taking multi-collinearity issues into account.

Considering the first equation (stated investment as a dependent variable), larger farms are more likely to have an intention to invest. This is consistent with expectations that farmers operating larger sized farms are more likely to be willing to invest because of the higher profitability derived from economies of scale. Larger farms are more likely to have developed the farming strategies, crop specialisations and managerial capacities to be able to cultivate large areas and they may be willing to maximise the value of these strategies through further expansion. However, the effect of farm size is not linear (squared total land has a significant coefficient). This coefficient is negative, which demonstrates that the relation between the probability to state an intention to invest and total land operated has a reverse U-shape. In other words, the marginal effect of size is decreasing and, if a farm becomes too large, it can become negative. The marginal impact of the farm size on investment is, however, rather small compared to the other significant effects.

We also observe a country effect on willingness to invest which is associated with different forms of direct payment implementation. Farmers receiving SAPS payments (Poland) are more likely to have the intention to invest compared to farmers receiving SFP. We know from the literature that SAPS may have a lower effect on marginal value of land than the SFP, which is based on historical payments (Guyomard, Le Mouël et al. 2004; Courleux, Guyomard et al. 2008; Ciaian and Kancs 2012; Kilian, Antón et al. 2012). However, when SAPS was introduced in Poland in 2006, the amount of the payment was very high compared to land prices, and SAPS payments were expected to increase in the following years. This may have encouraged farmers to buy land, or at least to be willing to do so (Marks-Bielska 2013). Moreover, in the new EU member states like Poland, the sales market for agricultural land is very dynamic, in particular thanks to the high profitability of farming and thanks to public sales under on-going land privatisation programmes (Ciaian, Kancs et al. 2012b). On the contrary, land markets are more rigid in Southern Europe, hence discouraging farmers' willingness to invest in land in those countries.

Individual farmers and more educated farmers are also more likely to have the intention to invest. This confirms that land purchase decision planning is a complex task that educated farmers can more easily perform. Once controlling for farm size, individual farmers are more likely to have the intention to invest, as they are more flexible than farms with several partners to take decisions.

Despite the fact that farmers were rather optimistic about future prices in 2006, these expectations, as well as those concerning farm succession, are not significant determinants of the intention to invest. The optimism with regard to prices is likely because previous years had seen rather stable prices and significant changes such as those that occurred during the 
2006-2009 period were not foreseen. The results concerning farm successors suggests that uncertainty concerning future farm operations by a family member is not overly important at

Table 3: Bivariate Recursive Probit: stated intention and realised investment

\begin{tabular}{|c|c|c|c|c|}
\hline & Coef. & $\begin{array}{l}\text { Robust } \\
\text { Std. Err. }\end{array}$ & & $\mathrm{P}>|\mathrm{z}|$ \\
\hline $\begin{array}{l}\text { statedInv (2006) } \\
\text { total_land } \\
\text { total_land_sq } \\
\text { land_owned } \\
\text { D_SAPS } \\
\text { D_crop } \\
\text { D_perenial } \\
\text { D_indfarm } \\
\text { head_age } \\
\text { head_edu } \\
\text { labour_int_2006 } \\
\text { labour_ext_2006 } \\
\text { D_suc_2006 } \\
\text { Expoutput_2006 }\end{array}$ & $\begin{array}{c}0.0182^{* * *} \\
-6.13 \mathrm{e}-05^{* *} \\
0.00377 \\
0.844^{* *} \\
0.221 \\
0.359 \\
0.837 * * \\
-0.0140 \\
0.186^{*} \\
4.44 \mathrm{e}-05 \\
-4.65 \mathrm{e}-05 \\
-0.175 \\
0.253\end{array}$ & $\begin{array}{l}.0069375 \\
.0000281 \\
.0053498 \\
.3762374 \\
.4119067 \\
.4062171 \\
4214424 \\
.0120128 \\
.1034972 \\
.0000505 \\
.0000412 \\
.3072676 \\
.1857805\end{array}$ & $\begin{array}{r}2.62 \\
-2.18 \\
0.71 \\
2.24 \\
0.54 \\
0.88 \\
1.98 \\
-1.16 \\
1.80 \\
0.88 \\
-1.13 \\
-0.57 \\
1.36\end{array}$ & $\begin{array}{l}0.009 \\
0.029 \\
0.480 \\
0.025 \\
0.592 \\
0.376 \\
0.047 \\
0.245 \\
0.072 \\
0.380 \\
0.258 \\
0.569 \\
0.174\end{array}$ \\
\hline $\begin{array}{l}\text { realizedInv } \\
\text { statedInv (2006) } \\
\text { total_land } \\
\text { D_SAPS } \\
\text { D_crop } \\
\text { D_perenial } \\
\text { D_indfarm } \\
\text { head_age } \\
\text { head_edu } \\
\text { labour_int_2009 } \\
\text { labour_ext_2009 } \\
\text { D_suc_2009 } \\
\text { Expoutput_2009 } \\
\text { Constant }\end{array}$ & $\begin{array}{c}2.753 * * * \\
-7.41 \mathrm{e}-05 \\
-0.883 * \\
0.263 \\
-0.664 \\
0.296 \\
-0.00989 \\
0.118 \\
-7.73 \mathrm{e}-06 \\
-0.000258^{* *} \\
-0.892 * * \\
0.377 * * \\
-1.583 \\
\end{array}$ & $\begin{array}{l}.6748331 \\
.0022214 \\
.5166563 \\
.3845881 \\
.5046674 \\
.5261508 \\
.0179664 \\
.1770844 \\
.0000552 \\
.0001251 \\
.3626258 \\
.1899042 \\
1.224504 \\
\end{array}$ & $\begin{array}{r}4.08 \\
-0.03 \\
-1.71 \\
0.68 \\
-1.31 \\
0.56 \\
-0.55 \\
0.67 \\
-0.14 \\
-2.06 \\
-2.46 \\
1.98 \\
-1.29 \\
\end{array}$ & $\begin{array}{l}0.000 \\
0.973 \\
0.088 \\
0.494 \\
0.189 \\
0.574 \\
0.582 \\
0.506 \\
0.889 \\
0.039 \\
0.014 \\
0.047 \\
0.196 \\
\end{array}$ \\
\hline $\begin{array}{l}\text { Observations } \\
\rho \\
\text { Wald test }(\mathrm{H} 0: \rho=0) \\
11(\text { model })=-97.61483 \quad \mathrm{df}=28\end{array}$ & $\begin{array}{c}131 \\
-.6194946 \\
\text { Chi2 }=1.96 \\
\text { AIC: } 251.2297\end{array}$ & \multicolumn{3}{|c|}{$\begin{array}{l}.3223608 \\
\text { Prob }>\text { Chi2 }=0.1662 \\
\text { BIC: } 331.7352 \\
\end{array}$} \\
\hline
\end{tabular}

$$
* * * \mathrm{p}<0.01, * * \mathrm{p}<0.05, * \mathrm{p}<0.1
$$


the time of planning investments, possibly because farmers expect the uncertainty to be resolved in the near future.

The absolute scale of the coefficients in a binary choice model gives a distorted picture of the response of the dependent variable to a change in one of the stimuli. Therefore, the interpretation of the second equation results (realised investment) is based on the marginal effects. We rely on the conditional marginal effects, which make more sense than the typical marginal effects in the recursive bivariate probit model (Park 2009). The calculation of marginal effects depends on whether the explanatory variable in question is binary or continuous. We follow Greene (1998)'s methodology on how to calculate marginal effects in a recursive bivariate probit model for the case where $\rho=0$. The estimation results for marginal effects are averaged across all observations. The averages, together with their standard errors, are reported in Table 4.

In the second equation, we find that the variable "stated investments" is positive and highly significant. Stating an intention to invest raises the probability of realising an investment by 21 per cent. Accordingly, it is a relevant proxy of investment, even in a period with important changes. Given that we control for intentions, we interpret the significativity of the financial and economic variables as potential drivers of the discrepancy between intentions and realizations. However, our dataset is limited in this sense and the variables included in the model certainly do not capture all the potential factors explaining the discrepancy.

We do not find any effect of farm size, suggesting that the stability of investment strategies does not depend on farm size. However, neither do we find that farms with larger amounts of employed external labour are more likely to deviate from their investment intentions. This may be due to the substitution effects between labour and land. Decisions to invest can evolve over time according to labour availability and the financial impact of labour costs that may deter investment. However, this can also be interpreted as the greater difficulty experienced by farms with external labour in maintaining their profitability and their intentions to expand in periods of crisis.

Polish farms (receiving SAPS payments) are also more likely to deviate from their initial investment plans. The rapid increase in land prices after the implementation of SAPS in Poland may explain the fact that farmers have not been able to realise their investments or that the profitability of farming relative to other sectors may have been lower than expected. The effect is significant in the coefficient estimation but not the marginal effect.

More interestingly, we find that farmers with positive expectations about future crop prices (they expect an increase in crop and livestock prices in the next 5 years - 2009-2014) are more likely to realise an investment. The fact that this variable becomes significant here, while it was not as a determinant of intention, can be plausibly interpreted as a hint to the fact that in periods of higher volatility and greater difficulty in predicting future scenarios, individual expectations can play a greater role in investment choices. In this sense it would more likely account for changes in external conditions between 2006 and 2009 than for differences between intentions and investment realisation. On the other hand, it is also plausible that expectations about the future become more relevant when an actual decision has to be made than when a simple intention is being requested.

On the contrary, farmers who were uncertain about future succession plans in 2009 are less likely to have invested between 2006 and 2009. Indeed, farms with uncertain succession plans 
may have decided not to continue the farming activity, especially in the context of the global economic crisis, and therefore prefer not to invest or postpone investments. Uncertainty in the future (both internal and market conditions) is therefore a driver of the discrepancy between realisations and intentions.

Table 4: Bivariate Recursive Probit - Conditional marginal effects $\operatorname{Pr}($ realizedInv=1 $\mid$ statedInv=1)

\begin{tabular}{|l|c|c|}
\hline & Total effects & $\mathrm{Z}$ \\
\hline statedInv (2006) & $0.210 * * *$ & 2.97 \\
total_land & 0.00304 & 1.09 \\
total_land_sq & $-1.03 \mathrm{e}-05$ & -0.97 \\
land_owned & 0.000637 & 0.64 \\
D_SAPS & -0.152 & -1.03 \\
D_crop & 0.135 & 0.83 \\
D_perenial & -0.159 & -1.12 \\
D_indfarm & $0.200 *$ & 1.71 \\
head_age & -0.00578 & -1.07 \\
head_edu & 0.0722 & 1.36 \\
labour_int_2006 & $7.50 \mathrm{e}-06$ & 0.72 \\
labour_ext_2006 & $-7.86 \mathrm{e}-06$ & -0.92 \\
D_suc_2006 & -0.0292 & -0.45 \\
Expoutput_2006 & 0.0427 & 0.80 \\
labour_int_2009 & $-2.68 \mathrm{e}-06$ & -0.14 \\
labour_ext_2009 & $-8.93 \mathrm{e}-05 * *$ & -2.26 \\
D_suc_2009 & $-0.259 * * *$ & -2.59 \\
Expoutput_2009 & 0.130 & 1.56 \\
\hline Observations & 131 & \\
\hline
\end{tabular}

$\$$ The marginal effect is significant at the $12 \%$ level ( $p$-value=0.119) $* * * \mathrm{p}<0.01, * * \mathrm{p}<0.05, * \mathrm{p}<0.1$ 


\section{Conclusion}

Intention studies are a growing branch of the agricultural economics literature, particularly in relation to ex-ante policy analysis. However, research on the stated intentions-realisation discrepancy in the field of agriculture is very limited. This is explained by practical difficulties in data collection (e.g. obtaining a constant sample) and in identifying appropriate variables to explain discrepancies due to the complexity of the decision-making process and the action schedule leading to major economic decisions, such as land purchases.

The database and methodology we use in this article partially overcomes these difficulties and offers some new insights into the conditions affecting the validity of intention surveys. We find that $74 \%$ of the respondents have followed their initial plans, which suggests that stated intentions are a good predictor of realised investments. This result is confirmed in the recursive bivariate probit model in which stated investment is a significant explanatory variable of actual investment. However, this result is partially weakened by the fact that the vast majority of farmers interviewed initially stated no intention to invest in land. This also accounts for the majority of cases in which intentions and actual realisations coincide, while only $36 \%$ of those who had planned to invest actually do so.

The above suggests that intentions may be a much more reliable predictor of actual behaviour when a conservative (no-investment) intention is expressed. Moreover, this paper provides some hints regarding the drivers which explain the gap between intentions and realised actions, which mostly apply to farmers initially intending to invest. We found that uncertainty concerning the existence of a successor reduces the likelihood a farmer will invest, even if he/she had planned to do so. We also found that changes in expectations with regard to future agricultural output prices are likely to generate a deviation between intentions and realisations. This has a dual meaning in the context of our study. First, perceptions may be seen as a proxy for external conditions that have in fact been changing substantially during the observed period. Secondly, it accounts for farmers "interpretations" of external conditions and their projection in the future. Finally, realisation was negatively related to use of external labour, which hints at the relevance of farm structure and organisation in "filtering" changes in external conditions.

Our results do not enable us to draw conclusions on whether the discrepancy between observed actions and stated intentions is too high to challenge the use of intentions surveys. They indicate, rather, that such a conclusion would be inappropriate and that it is more relevant to investigate the conditions under which stated intentions can indeed be trusted or when discrepancies can be expected. Our results, however, also show that these may be contingent upon the issues addressed.

The main limitations of the study are the limited sample size and the fact that some important variables likely to explain investments in land are unobserved (e.g. land market prices, farmers' preferences between land rental and land purchase). Hence, further research would be required in order to provide more robust corroboration of these results, if possible with a larger sample and a wider coverage of farm types. Moreover, further studies using a wider range of decision types (land investment, other investments, technology adoption, purchasing or selling options) would help to build a more systematic typology of the conditions that ensure the reliability of stated intentions.

For the purpose of future intention-based studies, our results corroborate the notion that clear assumptions about the future should be explicitly stated as a precondition for the reliability 
the intentions stated. They also suggest that information concerning farmers' expectations is important to collect in a stated intention survey, even when information about the actual economic environment at the time of the decision is already available.

In case the farmers' decisions to be studied are narrowly defined, a potential development could be to study the intention-behaviour discrepancy by way of more formalised Stated Preferences methods (e.g. choice experiment), rather than through simple open questions. The Stated Preference method refers to a family of techniques using individual respondents' statements about their preferences when faced with different alternatives which are options or situations constructed by the researcher (Kroes and Sheldon 1988). Stated Preference methods have several advantages. Because the researcher can define the conditions that are being evaluated by the respondents, it enables greater control and reduces the need to control for external drivers, as requested in revealed preferences methods. They may also be more flexible and cheaper to apply compared to alternative methods as each respondent provides multiple observations for variation in the variables which interest the researcher (Kroes and Sheldon 1988). Ideally, this line of research could lead to the identification of good practices in behaviour studies in agricultural economics and policy in order to add to the credibility and usability of survey-based agri-economic policy studies.

Acknowledgments: The authors would like to thank Pavel Ciaian and Sebastien Mary (European Commission, JRC IPTS) for their valuable comments. The two surveys on which this paper is based were funded by the IPTS, JRC-European Commission in the context of the projects "Investment behaviour in conventional and emerging farming systems under different policy scenarios", CONTRACT 150369-2005 and "Farm investment behaviour under the CAP reform process", CONTRACT 151247-2008. However, the views expressed are purely those of the authors and may not in any circumstances be regarded as stating an official position of the European Commission. 


\section{References}

Ajzen, I. (1991). "The theory of planned behavior." Organizational Behavior and Human Decision Processes 50(2): 179-211.

Allen, D. W. and D. Lueck (2002). The Nature of the Farm: Contracts, Risk, and Organization in Agriculture. Cambridge, MA, MIT Press.

Bagozzi, R. P. and Y. Yi (1989). "The Degree of intention Formation as a Moderator of the Attitude-Behaviour Relationship." Social Psychology Quarterly 52(4): 226-279.

Bartolini, F. and D. Viaggi (2011). Factors affecting the impact of CAP scenarios on farm structure: an analysis based on stated intentions. EAAE 2011 Congress, Change and Uncertainty Challenges for Agriculture, Food and Natural Resources. Zurich, Switzerland, ETH Zurich.

Bartolini, F. and D. Viaggi (2012). "The common agricultural policy and the determinants of changes in EU farm size." Land Use Policy.

Bougherara, D. and L. Latruffe (2010). "Potential impact of the EU 2003 CAP reform on land idling decisions of French landowners: results from a survey of intentions." Land Use Policy 27(4): 1153-1159.

Breustedt, G. and T. Glauben (2007). "Driving Forces behind Exiting from Farming in Western Europe." Journal of Agricultural Economics 58(1): 115-127.

Cattin, P. and D. R. Wittink (1982). "Commercial use of conjoint analysis: a review." Journal of marketing 46: 44-53.

Chandon, P., V. G. Morwitz, et al. (2005). "Do intentions really predict behaviour? Selfgenerated validity effects in survey research." The journal of marketing 69(2).

Ciaian, P. and d. A. Kancs (2012). "The Capitalization of Area Payments into Farmland rents: Micro Evidence from the New EU Menber States." Canadian Journal of Agricultural Economics 8(3).

Ciaian, P., D. A. Kancs, et al. (2010). "EU Land Markets and the Common Agricultural Policy." CEPS Paperbacks

Ciaian, P., d. A. Kancs, et al. (2012a). "Institutional Factors Affecting Agricultural Land Markets." Factor market working paper 16.

Ciaian, P., d. A. Kancs, et al. (2012b). "Key Issues and Developments in Farmland Sales Markets in the EU Member States and Candidate Countries." Factor market working paper 12.

Cohen, J. (1988). Statistical Power Analysis for the Behavioral Sciences, 2nd edition. Hillsdale, NJ, Lawrence Erlbaum Associates.

Courleux, F., H. Guyomard, et al. (2008). How the EU Single Farm Payment should be modelled: lump-sum transfers, area payments or... what else? Working Paper SMART - LERECO N08-01. Rennes, INRA UMR Smart.

Dong, F., D. A. Hennessy, et al. (2013). "Contract and exit decisions in finisher hog production." American Journal of Agricultural Economics 92(3): 667-684.

FAO (2010). The Impact of the Economic and Financial Crises on Agriculture and Food Security in Europe and Central Asia: a Compendium. Technical background paper for the Ministerial Round Table, 27th FAO Regional Conference for Europe, Yerevan 13 May 2010.

Feinerman, E. and J. Peerlings (2005). "Uncertain Land Availability and Investment Decisions: The Case of Dutch Dairy Farms, ." Journal of Agricultural Economics 56: 59-80.

Fishbein, M. and I. Azen (1975). Belief, Attitude, Intention and Behavior. An Introduction to Theory and Research, Addison-Wesley. 
Fujii, S. and T. Gärling (2003). "Application of attitude theory for improved predictive accuracy of stated preference methods in travel demand analysis." Transp. Res. Part A 37: 389-402.

Greene, W. (1998). "Gender Economics Courses in Liberal Arts Colleges: Further Results." Journal of Economic Education 29: 291-300.

Greene, W. (2011). Econometric Analysis, 7th edition, Upper Saddle River.

Guyomard, H., C. Le Mouël, et al. (2004). "Impacts of Alternative Agricultural Income Support Schemes on Multiple Policy Goals." European Review of Agricultural Economics 31(2): 125-148.

Harvey, D. R. (2000). Farmers' Intentions Survey, 1994-1997. Final Report., University of Newcastle upon Tyne.

Heckman, J. (1978). "Dummy Endogenous Variables in a Simultaneous Equation System." Econometrica 46: 931-959.

Hennessy, D. A. (1998). "The production effects of agricultural income support policies under uncertainty." American Journal of Agricultural Economics 80: 46-57.

Horowitz, J. K. (1992). " A test of intertemporal consistency." Journal of Economic Behavior \& Organization 17: 171-182.

Just, R. E. (2008). "Distinguishing preferences from perceptions for meaningful policy analysis." American Journal of Agricultural Economics 90 (5): 1165-1175.

Kilian, S., J. Antón, et al. (2012). "Impacts of 2003 CAP Reform Land Rental Prices and Capitalization." Land Use Policy 29: 789- 797.

Knighta, J., S. Weirb, et al. (2003). "The role of education in facilitating risk-taking and innovation in agriculture." Journal of Development Studies 39(6).

Koundouri, P., M. Laukkanen, et al. (2009). "The effects of EU agricultural policy changes on farmers' risk attitudes." European Review of Agricultural Economics 36: 53-77.

Kroes, E. P. and R. J. Sheldon (1988). "Stated preference method: an introduction." Journal of transport economics and policy XX11(1): 11-25.

Lagerkvist, C. J. (2005). "Agricultural policy uncertainty and farm level adjustments-the case of direct payments and incentives for farmland investments." European review of agricultural economics 32(1): 1-23.

Louviere, J. J., D. A. Hensher, et al. (2000). Stated Choice Methods: Analysis and Application, Cambridge University Press.

Maddala, G. S. (1983). Limited Dependent and QualitativeVariables in Econometrics. Cambridge, UK, Cambridge University Press.

Manski, C. F. (1990). "The use of intentions data to predict behaviour: a best-case analysis." Journal of the American Statistical Association 85(412): 934-940.

Marks-Bielska, R. (2013). "Factors shaping the agricultural land market in Poland." Land Use Policy 30: 791-799.

Mattison, E. H. A. and K. Norris (2007). "Intentions of UK Farmers toward Biofuel Crop Production: Implications for Policy Targets and Land Use Change." Environmental Science Technology 41(16): 5589-5594.

Mishra, A. K., M. Raggi, et al. (2010). Determinants of farm exit: A comparison between Europe and United States European Association of Agricultural Economists, 114th Seminar,. Berlin, Germany.

Mitchell, P. D., R. M. Rejesus, et al. (2011). "Analyzing Farmer Participation Intentions and County Enrollment Rates for the Average Crop Revenue Election Program." Applied Economic Perspectives and Policy 34: 615-636.

O'Neill, S. and K. Hanrahan (2012). "Decoupling of agricultural support payments: the impact on land market participation decisions." European Review of Agricultural Economics 39(4): 639-659. 
Park, H. M. (2009). Regression Models for Binary Dependent Variables Using Stata, SAS, R, LIMDEP, and SPSS. Working Paper, The University Information Technology Services (UITS) Center for Statistical and Mathematical Computing, Indiana University.

Pyndick, R. S. (1991). " Irreversibility, Uncertainty, and Investment." Journal of Economic Literature 29(3): 1110-1148.

Raggi, M., L. Sardonini, et al. (2012). "The effects of the Common Agricultural Policy on exit strategies and land re-allocation." Land Use Policy.

Sckokai, P. and D. Moro (2009). "Modelling the impact of the CAP Single Farm Payment on farm investment and output." European Review of Agricultural Economics 36(3): 395-423.

Thomson, K. J. and A. W. Tansey (1982). "Intentions Surveys in Farming." Journal of Agricultural Economics 33(1): 83-88.

Vare, M., C. R. Weiss, et al. (2005). On the intention-behaviour discrepancy: empirical evidence from succession on farms in Finland. Vienna University discussion paper $\mathrm{n} 3$.

Vercammen, J. (2007). "Farm bankruptcy risk, direct payments and agricultural investment." European Review of Agricultural Economics 34: 479-500.

Viaggi, D., M. Raggi, et al. (2011a). "Farm-household investment behaviour and the CAP decoupling: Methodological issues in assessing policy impacts." Journal of Policy Modeling 33: 127-145.

Viaggi, D., M. Raggi, et al. (2011b). "Understanding the determinants of investment reactions to decoupling of the Common Agricultural Policy." Land Use Policy 28: 495-505.

Weiss, C. R. (1998). "Size, growth, and survival in the upper Austrian farm sector. ." Small Business Economics 10: 305-312.

Wong, J. K. and J. N. Sheth (1985). Explaining intention-behaviour discrepancy: a paradigm. Advances in Consumer Research. E. C. Hirschman and M. B. Holbrook, Provo, UT : Association for Consumer Research. 12: 378-384. 
